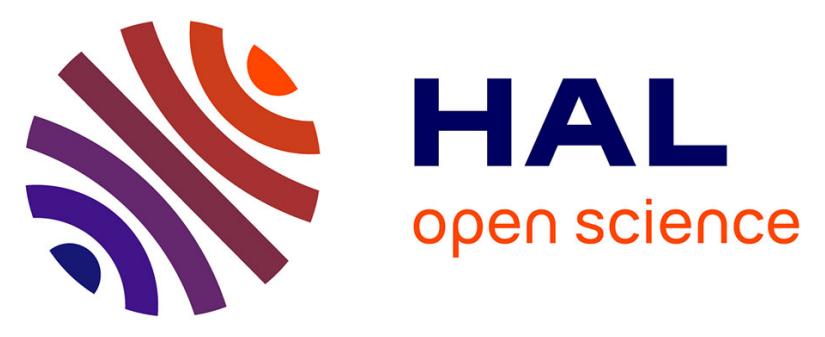

\title{
What is hot in tree rings? The wood density of surviving Douglas-firs to the 2003 drought and heat wave
}

Alejandro Martinez Martinez-Meier, Léopoldo Sanchez, Mario Pastorino, Leonardo Gallo, Philippe P. Rozenberg

\section{- To cite this version:}

Alejandro Martinez Martinez-Meier, Léopoldo Sanchez, Mario Pastorino, Leonardo Gallo, Philippe P. Rozenberg. What is hot in tree rings? The wood density of surviving Douglas-firs to the 2003 drought and heat wave. Forest Ecology and Management, 2008, 256 (4), pp.837-843. 10.1016/j.foreco.2008.05.041 . hal-02663742

\section{HAL Id: hal-02663742 \\ https://hal.inrae.fr/hal-02663742}

Submitted on 31 May 2020

HAL is a multi-disciplinary open access archive for the deposit and dissemination of scientific research documents, whether they are published or not. The documents may come from teaching and research institutions in France or abroad, or from public or private research centers.
L'archive ouverte pluridisciplinaire HAL, est destinée au dépôt et à la diffusion de documents scientifiques de niveau recherche, publiés ou non, émanant des établissements d'enseignement et de recherche français ou étrangers, des laboratoires publics ou privés. 


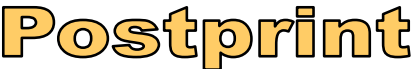

Version définitive du manuscrit publié dans / Final version of the manuscript published in :

In Forest Ecology and Management. 2008, 256(4), 837-843

What is hot in tree rings? The wood density of surviving Douglas-firs to the 2003 drought and heat wave.

Martinez-Meier Alejandro ${ }^{*}{ }^{12}$, Sanchez Leopoldo ${ }^{2}$, Pastorino Mario ${ }^{13}$, Gallo Leonardo ${ }^{1}$, Rozenberg Philippe ${ }^{2}$.

${ }^{1}$ INTA Bariloche, Unidad de Genética Forestal. C.C. 277, (8400), S.C. de Bariloche, Argentina. Email: almarti@bariloche.inta.gov.ar

* 2 INRA Orléans, Unité Amélioration Génétique et Physiologie Forestières, 2163 Avenue de la Pomme de Pin, BP 20619 Ardon, 45166 Olivet Cedex, France. Email:

alejandro.martinez@orleans.inra.fr

${ }^{3}$ Consejo Nacional de Investigaciones Científicas y Técnicas (CONICET).

* Current author address

Telephone number: +33-+238417873

Fax number: +33-+238417879

Email: alejandro.martinez@orleans.inra.fr

Keywords: heat wave, climate change; phenotypic plasticity; adaptation; microdensity profile; Pseudotsuga menziesii 


\begin{abstract}
In a global warming scenario, drought and heat waves like the one that occurred in 2003 in Europe are expected to become more intense and frequent. This extreme climate event strongly affected the hydraulic balance in many forest tree species including Douglas-fir, with symptoms ranging from partial crown necrosis to death. We studied a French Douglas-fir provenance trial, strongly affected by the 2003 drought and heat wave. Using wood X-ray microdensity profiles as a record of cambium response to environmental variations, we compared mean stem density and growth between dead and alive neighbouring trees and several microdensity characters measured over 17 growth rings previous to 2003. Special attention has been given to the sampling layout in order to minimize the micro-environmental effects. At tree level, surviving trees have a significantly higher mean stem density. At tree ring level, they have a significantly higher mean ring density, maximum ring density, latewood density and, to a lesser extent, latewood proportion. No significant difference was found for diameter growth. These results could have direct implications in the way to study and predict possible acclimation and adaptation of forest trees to climate change process. Wood could be used for the selection of genotypes with a desirable plasticity and resistance to drought induced-cavitation.
\end{abstract}




\section{Introduction}

Wood is a temporal record of tree by environment interactions. In a typical temperate conifer tree, early-season growth produces wood cells (tracheids) with thin walls and big diameter lumens commonly called earlywood. Towards the end of the growing season, tracheids are formed with thick walls and small diameter lumens named latewood. The anatomical change through the growing season is easily revealed by an increase in within ring wood density, which forms the well known pattern of earlywood-latewood concentric growth rings. However, tree response to environmental conditions also happens at lower physical and temporal scales. For instance, discrete drought events during the growing season can trigger remarkable peaks of density in the wood, called false rings (Zahner, 1968; Glerum, 1970; Rozenberg et al., 2002).

Wood density record reflects the cambial activity of a plant caused by environmental signals, and wood density profiles can be used to infer individual plasticity. Here, we define plasticity as the capacity of a given genotype to modify its phenotype as a response to environmental variations (DeWitt and Scheiner, 2004). Plasticity is thus an individual response, different from evolution, which is generally defined as a successful change through selection in the genetic composition of a population submitted to an environmental shift. Up to now, between-ring wood records have been the focal interest of dendrochronology, relying on large temporal series at population level to study local climate variations (Douglass, 1933; Fritts, 1976). Smaller scale within-ring variations at individual level as response to climatic events have received less attention (Rozenberg et al., 2001).

The different types of wood formed during early and late growing season have very different hydraulic properties (Domec and Gartner, 2001). In Douglas-fir, under normal climate conditions, sap flows in latewood tracheids could be neglected compared to early-season tracheids (Domec and Gartner, 2002). Hydraulic imbalances, as a result of low soil water content and strong atmospheric demands, can induce generalized cavitation in xylem tracheids (Tyree and Sperry, 1989; Domec and Gartner, 2002; Taiz and Zeiger, 2006). This unfavourable phenomenon occurs when, following a sudden water deficit, the internal pressures become negative enough to overcome the potential of xylem dysfunction (Cochard, 1991) and the water column inside the tracheids breaks (Tyree and Zimmermann, 2002). Ultimately, adult trees may die as a result of long and/or intense drought events (Mueller et al., 2005; Bréda et al., 2006).

Within the global warming perspective, extreme climate events are expected to increase in frequency and intensity (Levinson et al., 2003; Meehl et al., 2004; Schär et al., 2004; Salinger, 2005; IPCC, 2007), providing forest trees little opportunity to migrate or to evolve in place (St. Clair \& Howe, 2007). Therefore phenotypic plasticity could play a principal role in the acclimation or/and adaptation process to the new climate changes scenario. The year 2003 in Europe was considered a signal of the global warming process, being for instance the most severe heat wave in France since the year 1370 (Chuine et al., 2004). Abnormal ecophysiological reactions were reported as consequences of this heat wave in many trees (Bréda et al., 2004). Douglas-fir (Pseudotsuga menziesii (Mirb.) Franco), a conifer species planted abundantly in Europe and particularly in France (De Champs, 1997; Thivolle-Cazat, 2004), was strongly affected (DSF, 2004; Rozenberg and Pâques, 2004; Martinez-Meier et al., 2008). Symptoms ranged from partial foliage necrosis to individual death. Yet, some Douglas-firs neighbouring the affected trees had no visible damage. The genetic background and the micro-environmental conditions certainly play an essential role in tree survival. Besides that, we questioned whether the wood of dead and living trees, as records of their particular reactions to past weather, showed a systematic difference that could hint a lack in plasticity or adaptation in the dead trees. As far as we know, this kind of study has not been undertaken yet. In species with great water demand, like Douglas-fir, the global warming 
process could act as a strong selective force. Under extreme climate events, wood density changes would have an impact on the integrity of trees hydraulic system and, ultimately, affect their fitness.

By using fine scale analysis of wood records based on X-ray microdensity profiles, we compared microdensity parameters between Douglas-fir individuals that had not survived the drought and heat wave of 2003 and their neighbouring surviving trees. Attention has been given to the sampling layout and the statistical analysis in order to minimize the microenvironmental effects. The eventual use of certain wood record characteristics to predict a tree's potential acclimation was subsequently discussed. 


\section{Material and Method}

We identified 65 dominant adult trees that were dead soon after the 2003 drought and heat wave. All dead trees presented the same damage, a total foliage necrosis. These trees were part of a large Douglas-fir provenance trial established in March 1975, located in Region Centre, France ( $\left.2^{\circ} 16^{\prime} \mathrm{E}, 47^{\circ} 57^{\prime} \mathrm{N}\right)$. The trial site receives a mean annual precipitation of $690 \mathrm{~mm}$ and has flat sandy soil. A wood sample from each of the 65 dead trees was obtained coupled with another wood sample from the nearest dominant living tree, resulting in 65 dead vs. alive pairs of trees. Collection date was between April and June 2006. Sixty provenances were represented in the sample, thus most of them have only one tree per provenance. Wood samples consisted of $5 \mathrm{~mm}$ diameter increment cores, taken perpendicularly at the stem axis at breast height. No fungal or/and others damages were found in the increment cores of sampled trees. Increment cores were analyzed by indirect X-ray densitometry (Polge, 1966) and the resulting X-ray films were scanned at a 1000 dpi resolution with 8 bits depth per pixel. The digital images were processed with WinDENDRO software (Guay, 1992), obtaining a final spatial resolution of $25 \mu \mathrm{m}$.

The complete density profiles (Fig. 1) were used to estimate mean stem density and diameter growth for each tree following the methodology described in Rozenberg et al. (1997).

Fig. 1 Microdensity profiles of two trees: one tree that survived 2003 but perished in the following year and a surviving tree, from our sample in Orléans Douglas-fir forest.

Microdensity data was computed yearly from 1986 to 2002 rings (seventeen years), by using a function written in $R$ language ( $R$ Development Core Team, 2007). We described each of the tree-rings of the above period by seven of the most commonly used descriptors among users of microdensity profiles. These descriptors were: ring width, mean ring density, minimum ring density, maximum ring density, earlywood density, latewood density and latewood proportion. Earlywood and latewood densities were taken as the average density of their respective ring portion computed by the mean of the extreme density values in each ring (Zamudio et al., 2005). In order to avoid the eventual effects of a non-random distribution of dead trees across the trial, and minimize the impact of micro-environmental differences onto the dead versus surviving comparison, each dead tree was systematically associated to an adjacent living tree with no apparent signs of damage (Fig. 2). We assumed, therefore, that each living tree shares the same physical environment than its associated dead tree.

Fig. 2 Tree distribution in provenance trail and pairs of sampled trees (dead and associate living trees).

Then, the difference between the value of the living tree and the value of its associated dead tree was computed for: mean stem density, diameter growth and for seven ring variables, in all years. Resulting means over the 65 pairs for each variable were computed (denoted D1 to the observed mean difference in mean stem density and diameter growth and $D 1_{i j}$ for variable $\mathrm{i}$ in year $\mathrm{j}$ in the case of ring variables). In order to construct a reference distribution for each estimator (mean stem density, diameter growth and 7 ring variables times 17 years), from which inferences over $D 1$ and $D 1_{i j}$ could be made, we used a Monte-Carlo randomization approach (Mainly, 1997).

This randomization approach used as reference population all the trees of the analyzed 65 pairs. These 65 random pairs were subsequently formed from this reference population, without replacement and with no consideration of health status, and differences for all variables computed and stored. This re-sampling preceded over 1000 replicates, and distributions for all variables were constructed across the replicates. These distributions 
corresponded to the expected difference between any two given trees, D0, or a difference that is due purely to chance. Randomization was carried out using a Monte-Carlo routine written in $R$ language ( $R$ Development Core Team, 2007).

Each observed difference, D1 (for mean stem density and diameter growth) and $\mathrm{D} 1_{\mathrm{ij}}$ (7 ring variables from 1986 to 2002), was compared to its corresponding distribution of $\mathrm{D} 0$ and $\mathrm{D} 0_{\mathrm{ij}}$, and the standardized area left to the right by $\mathrm{D} 1$ and $\mathrm{D} 1_{\mathrm{ij}}$ in the distribution of $\mathrm{D} 0$ and $\mathrm{D} 0_{\mathrm{ij}}$ was computed as the probability of the observed difference being due by chance, respectively. We assumed a significance threshold of 0.05 , for a one tail test. 


\section{Results}

In preliminary analyses, not presented here, we did not found significant provenance effect for crown symptoms following the 2003 drought and heat wave. However, the provenance structure of the trial was strongly unbalanced at the date of the sample collection, because the trial had already been thinned twice, which left many provenances with very few trees and significantly decreased the statistical power of the original experimental design.

For all the surviving trees, the last complete ring in the microdensity profiles was the ring before the collection date, ring 2005. For the dead trees, the last complete ring was that of 2003 for 51 trees, ring 2004 for 8 trees and ring 2005 for 6 trees. That means that 15 dead trees did not die immediately after 2003, but one or two years later. Nevertheless, rings 2004 and 2005 of these latter trees were all very narrow, typical of trees under stress (Fig. 1). Table 1 shows averages and confidence intervals for dead and living trees for mean stem density and diameter growth. The result shows that surviving trees have a significantly higher mean density than dead trees, but are not significantly different for diameter growth.

Table 1 Average, D1 differences and standard deviation and p-value for mean stem wood density and diameter growth in surviving and dead Douglas-fir trees.

Figure 3 and 4 show the development of differences $\left(D 1_{i j}\right)$ between the surviving and the dead trees over years, as well as the associated levels of significance. The grey bars values over the horizontal line correspond to significant differences from what would be expected from a random pair, thus meaning that the surviving trees are significantly different from the dead trees.

Fig. 3 Differences between living and dead trees for variable i and year j (D1 $1_{i j}$ ) for ring width (a), minimum ring density (b) and earlywood density (c) in solid line. The solid grey bars show the $\log 10$ of the probability associated to $\mathrm{D} 1_{\mathrm{ij}}$ in the Monte-Carlo randomization process. The horizontal line represents the $5 \%$ significance level.

For these three variables in figure 3, the surviving trees appeared not to be significantly different from their dead counterparts, except in ring-years 2000 and 2001 for ring width, in ring-years 1994 and 1997 for minimum ring density and in ring-years 1994, 1995 and 1997 for earlywood density.

In a similar way as in figure 3, figure 4 represent results for mean ring density (a), maximum ring density (b), latewood density (c) and latewood proportion (d).

Fig. 4 Differences between living and dead trees in variable i in year j (D1 $\left.1_{\mathrm{ij}}\right)$ for mean ring density (a), maximum ring density (b), latewood density (c) and latewood proportion (d). The solid grey bars show the $\log 10$ of the probability associated to $\mathrm{D} 1_{\mathrm{ij}}$ in the Monte-Carlo randomization process. The horizontal line represents the $5 \%$ significance level.

Dead and surviving trees appeared to be significantly different for mean ring density, maximum ring density and latewood density from 1994 to 2002, except for maximum ring density in 1998. Dead and surviving trees were significantly different too for the three previous variables in 1990 and in 1991 for latewood density. For latewood proportion (d), the surviving and the dead trees are significantly different from 1999 to 2002.

The significant differences between surviving and dead trees were related generally to the second part of the growing season. Surviving trees tend to have a higher latewood density and a higher latewood proportion in the outermost ring (Fig. 5). 
Fig. 5 Illustration of the mean latewood density and mean latewood proportion in living (dark grey circles) and dead (light grey diamonds) trees, for the outermost yearrings (from 1999 to 2002). Full big circle and diamond and their solid lines represent the mean value and standard deviation of each group of trees (living and dead trees respectively). 


\section{Discussion}

4.1. Wood density and its implication on tree hydraulics.

One of the main consequences of the 2003 drought and heat wave for the trees was a dramatic reduction in growth, which is usually operated through stomata closure as response to a strong atmospheric demand and to a decrease in soil water availability (Bréda et al., 2004; 2006). If drought increases in length and intensity, cavitation is likely to occur in the xylem, followed by early mortality of roots and twigs (partial necrosis) and, ultimately, by tree death (Mueller et al., 2005; Bréda et al., 2006).

In Douglas-fir, under favorable hydraulic conditions, water transport is mainly (more than 80 \%) done through the earlywood of the outermost rings (sapwood) (Domec \& Gartner, 2002). The research described in this paper shows that the trees that survived the 2003 extreme drought and heat wave have in several previous to 2003 tree rings, a higher mean ring density due to a higher proportion of denser latewood. Thus the significant differences in the latewood components found in this study, principally in the outermost rings, suggest that variation in latewood characteristics may be related to resistance to drought, helping trees to maintain the integrity of their hydraulic system.

The corresponding hypothesis is that their latewood quantity and characteristics increase the resistance to cavitation. In other words, a higher proportion of higher latewood density tends to increase resistance to drought. If this was the case, what was the physiological mechanism involved? We assume that the death of a number of trees following the 2003 climate event is a consequence of a generalized embolism in conductive rings. Conversely, the survival of other trees is certainly related to a better preservation of conductivity in their hydraulic system. How a higher proportion of higher density latewood may explain the preservation of the conductivity? Some authors emphasize that high latewood/earlywood ratio could be an adaptive hydraulic trait in Douglas-fir (Domec \& Gartner, 2002), others highlight the water storage capacity of latewood (Waring \& Running, 1978; Beedlow et al., 2006) that could be made available after earlywood becomes no longer conductive (Schiller \& Cohen, 1995; Domec \& Gartner, 2002).

The apparition and propagation of embolism can be explained, by xylem structure, i. e. wall thickness/lumen diameter ratio and/or pit characteristics (Cochard, 1991; Sperry et al., 2006; Pittermann et al., 2006). At least in Douglas-fir, density is strongly related with lumen diameter (Rathgeber et al., 2006). According to our knowledge no results have been published about a possible relationship between wood density and pit characteristics. Is the variation of lumen diameter alone able to explain the observed mortality rate? Does the observed variation for latewood proportion and density is large enough to explain a delayed apparition and propagation of embolism in the surviving trees? Simultaneous studies taking into account the variation of ring density components and adaptive traits related to wood conduction properties and/or wood anatomical characteristic are necessary to try to answer these questions.

\subsection{Xylem plasticity}

During a growing season, wood density follows a curve that reflects cambial activity as a function of environmental variations (Zahner, 1968; Sanchez-Vargas 2007). This can be interpreted as the way in which a particular genotype responds to environmental variations, and that is a measure of phenotypic plasticity. With a rapid global warming scenario (IPCC, 2007), this individual plastic response may play an important role in the acclimation to new environmental conditions (Bréda et al., 2006; Rennenberg et al., 2006; Saxe et al., 2006). In forest species with long generation periods, trees that respond to environmental shifts with beneficial phenotypic changes can have more chance of survival. Our results suggest that surviving trees responded by producing a particular type of latewood, showing certain responsiveness to the environmental stress produced by summer conditions during the last 
part of the growing seasons and that dead trees lacked. This distinctive response was systematic over several years before 2003, and was not restricted to punctual discrete annual events.

The significant differences that we found between the dead and the surviving trees can be interpreted as a faster transition during the growing season from a similar earlywood to a higher density latewood for the surviving trees. In other words, the surviving trees were more plastic than the dead trees. But, to confirm this hypothesis, it is necessary to synchronize wood formation and climate variation, since in the microdensity profiles wood variation describes distance and not time. This synchronization is the subject of another, on-going study. If the increase of the latewood density components is truly related to resistance to drought, which is still to be proved, then the surviving trees could be regarded as more plastic in terms of wood formation and improving their resistance to drought. The plasticity of wood formation (i.e. xylem plasticity) as a function of climate deserves greater attention when studying the biology of adaptation. The approach using dead versus surviving trees following extreme events may be fruitful in the study of plasticity and adaptation over future climates.

\subsection{Long-term response.}

At the risk of oversimplification, keeping in mind the relatively limited scope of this study, we could assume that some degree of selection against trees with low density wood may happen after heat wave events like the one in 2003. This kind of event might become more frequent under the general scenario of climate change (Meehl et al., 2004; IPCC, 2007), where not only an increase in mean temperature is expected, but what is more important, an increase in variation in temperatures and precipitations. Therefore, repeated events of extreme heat might subsequently deplete low density trees in favour of those with higher density. Moreover, many references state the high levels of genetic control behind wood density characteristics (Zobel and van Buijtenen, 1989; Zobel and Jett, 1995). This is particularly evident in Douglas-fir (Gonzalez and Richards, 1988; King et al., 1988; Loo-Dinkins and Gonzalez, 1991; St. Clair, 1994; Vargas-Hernandez et al., 1994; Johnson and Gartner, 2006). High heritability traits subjected to directional selection are expected to yield rapid phenotypic shifts. However, whether this phenotypic drift is actually occurring or not is beyond the scope of this study. We could also assume that neither wood density nor its basic components are direct targets of natural selection. Although the link between wood density and tree hydraulic properties seems a good conceptual approach, natural selection could operate on other basic traits having as side-effect an increase in wood density. This could happen through underlying pleiotropy or by physical constraints.

We should note nevertheless that Douglas-fir is a relatively young introduction in France, directly from their natural habitats on the West coast of North America.

\subsection{Consequences in tree breeding programs.}

Up to now studies of wood physical properties have had principally two distinct objectives: the study of wood quality and the reconstruction of past climates (i.e. dendrochronology). Few attempts have been made to use wood density as an indicator of the reaction of trees to immediate climate, and as a measure of plasticity; that is malleable by directional selection (Scheider and Lyman, 1989; Gibert et al., 2004). Recently, some authors pointed at this possibility, by showing that some microdensity variables are good indicators of extreme climate events (Rozenberg et al., 2002; Bower et al., 2005; Martinez-Meier et al., 2008), and that they seem to have significant genetic control (Rozenberg et al., 2004; Martinez-Meier et al., 2008).

\section{Conclusions}


Trees surviving 2003 heat and drought wave have a significantly higher mean ring density, higher latewood density and higher latewood proportion. The increased latewood density components in surviving trees could be related to xylem plasticity and this could be linked to a resistance to drought.

We showed in this study that it may be possible to predict the susceptibility to extreme climates events on the basis of ring density parameters. Microdensity profiles are useful to infer the plasticity of wood formation related to climate variation and tree adaptation in the context of the global warming scenario. This opens up possibilities in tree breeding programs, because mean ring density is under high genetic control, and could be considered as a candidate to improve drought tolerance. Moreover, wood density is usually positively correlated with overall wood quality. In any case, it will be necessary to validate these results over a wider range of populations, to confirm the adaptive value of wood density, as well as to quantify the genetic variability for these traits in remaining French Douglas-fir populations. 


\section{Acknowledgments}

We would like to thank Frédéric Millier for helping us with the X-ray microdensity profiles and Guillermina Dalla-Salda for her valuable commentaries in the revision versions of the manuscript. Research was funded by Project Alfa II-266 GEMA (GEnética de la MAdera), supported by European Commission and the plant material that was used in this study was provided by INRA Orléans. We thank the anonymous reviewers for the valuable and helpful commentaries that helped us to improve substantially the final version of this manuscript. 


\section{References}

Beedlow. P., Tingey, D., Waschmann, R.; Phillips, L., Johnson, M., 2006. Bole water content shows little seasonal variation in century-old Douglas-fir trees. Tree Physiol. 27, 737-747. Bower, A., Adams, T.W., Birkes, D., Nalle, D., 2005. Response of annual growth ring components to soil moisture deficit in young, plantation-grown Douglas-fir in coastal British Columbia. Can. J. For. Res. 35, 2491-2499.

Bréda, N., Granier, A., Aussenac, G., 2004. La sécheresse de 2003 dans le contexte climatique des 54 dernières années: analyse écophysiologique et influence sur les arbres forestiers. Revue Forestière Française 56, 109-131.

Bréda, N., Huc, R., Granier, A., Dreyer, E., 2006. Temperate forest trees and stands under severe drought: a review of ecophysiological responses, adaptation processes and long-term consequences. Ann. For. Sci. 63, 625-644.

Bucci, S., Goldstein, G., Meinzer, F., Scholz, F., Franco, A., Bustamante, M., 2004.

Functional convergence in hydraulic architecture and water relations of tropical savanna trees: from leaf to whole plant. Tree Physiol. 24, 891-899.

Carlquist, S., 1985. Vasicentric tracheid as a drought survival mechanism. Aliso 11, 37-68. Chuine, I., Yiou, P., Viovy, N., Seguin, B., Daux, V., Le Roy Ladurie, E., 2004. Historical phenology: Grape ripening as a past climate indicator. Nature 432, 289-290.

Cochard, H., 1991. Vulnerability of several conifres to air embolism. Tree Physiology 11, 7383.

Cochard, H., Peiffer, M., Le Gall, K., Granier, A., 1997. Developmental control of xylem hydraulic resistances and vulnerability to embolism in Fraximus excelsior L. impacts on water relation. J. Exp. Bot. 48, 655-663.

De Champs, J., 1997. Le Douglas. Afocel, Paris.

Dewitt, T., Scheiner, S.M., 2004. Phenotypic Plasticity. Functional and Conceptual Approaches. Oxford University Press, Inc.

Domec, J.C., Gartner, B.L., 2001. Age- and position-related changes in hydraulic versus mechanical dysfunction of xylem: inferring the design criteria for Douglas-fir wood structure. Tree Physiol. 22, 91-104.

Domec, J.C., Gartner, B.L., 2002. How do water storage differ in coniferous earlywood and latewood?. J. Exp. Bot. 53, 2369-2379.

Douglass, A.E., 1933. Evidences of Cycles in Tree Ring Records. In: Proceedings of the National Academy of Sciences of the United States of America 19, 350-360.

Département de la Santé des Forêts, 2004. Sécheresse et canicule de l'eté 2003. Quelle incidence visuelle sur les peuplements forestiers? Information Santé des Forêt. Available in: http://www.agriculture.gouv.fr/spip/IMG/pdf/isfweb_long.pdf Fritts, H.C., 1976. Tree rings and climate. Academic Press, London.

Gibert, P., Moreteau, B., David J.R., 2004. Phenotypic plasticity of body pigmentation in Drosophila melanogaster. Genetic repeatability of quantitative parameters in two successive generations. Heredity 92, 499-507.

Glerum, C., 1970. Drought ring formation in conifers. For. Sci. 16, 246-248.

Gonzalez, J.S., Richards, J., 1988. Early selection for wood density in young coastal Douglasfir trees. Can. J. For. Res. 18, 1182-1185.

Guay, R., Gagnon, R., Morin, H., 1992. A new automatic and interactive tree ring measurement system based on a line scan camera. For. Chronicle. 68, 138-141.

Hacke, U., Sperry, J., Pockman, W., Davis, S., McCulloh, K., 2001. Trends in wood density and structure are linked to prevention of xylem implosion by negative pressure. Oecologia, 126, 457-461.

IPCC 2007, 2007. Climate Change 2007: The Physical Science Basis. Summary for Policymakers. Contribution of Working Group I to the Fourth Assessment Report of the 
Intergovernmental Panel on Climate Change. Available in:

http:/www.ipcc.ch/SPM2feb07.pdf

Johnson, G.R., Gartner, B., 2006. Genetic variation in basic density and modulus of elasticity of coastal Douglas-fir. Tree Genetics \& Genomes. 3, 25-33.

King, J.N., Yeh, F., Heaman, J., Dancik, B., 1988. Selection of Wood Density and Diameter in Controlled Crosses of Coastal Douglas-fir. Silvae Genetica. 37, 152-157.

Levinson, D.H., Waple, A.M., 2004. State of the Climate in 2003. Bull. Am. Meteorol. Soc. 85, $72 \mathrm{p}$.

Loo-Dinkins, J.A., Gonzalez, J.S., 1991. Genetic control of wood density profile in young Douglas-fir. Can. J. For. Res. 21, 935-939.

Mainly, B., 1997. Randomization, Bootstrap and Monte Carlo Methods in Biology, Second Edition. Chapman \& Hall/CRC.

Martinez-Meier, A., Sanchez, L., Dalla-Salda, G., Pastorino, M., Gautry, J.Y., Gallo, L., Rozenberg, P., 2008. Genetic control of the tree-ring response of Douglas-fir (Pseudotsuga menziesii (Mirb.) Franco) to the 2003 drought and heat-wave in France. Ann. For.Sci. 65. Available in: www.afs-journal.org.

Meehl, G., Tebaldi, C., 2004. More Intensive, More Frequent, and Longer Lasting Heat Waves in the 21st Century. Science 305, 994.

Mueller, R., Scudder, C., Porter, M., Talbor-Trotter III, R., Gehring, C., Whitham, T., 2005. Differential tree mortality in response to severe drought: evidence for long-term vegetation shifts. J. Ecology. 93, 1085-1093.

Pittermann J., Sperry J.S., Wheeler J.K, Hacke U.G., Sikkema E.H., 2006. Mechanical reinforcement of tracheids compromises the hydraulic efficiency of conifer xylem. Plant Cell Environ. 29, 1618-1628.

Polge, H., 1966. Etablissement des courbes de variations de la densité du bois par exploration densitométrique de radiographies d'échantillons prélevés à la tarière sur des arbres vivants. Application dans les domaines technologiques et physiologiques. PhD thesis, Université de Nancy, Nancy 215 pp.

Rathgeber C., Decoux V., Leban J.M., 2006. Linking intra-tree-ring wood density variations and tracheid anatomical characteristics in Douglas fir (Pseudotsuga menziesii (Mirb.) Franco). Ann. For. Sci. 63, 699-706.

R Development Core Team, 2007. R: A language and environment for statistical computing, R Foundation for Statistical Computing. Vienna, Austria. Available in: http://www.Rproject.org.

Rennenberg, H., Loreto, F., Polle, A., Brilli, F., Fares, S., Beniwal, R.S., Gessler, A. 2006. Physiological responses of forest trees to Heat and Drought. Plant Biol. 8, 556-571.

Rozenberg, P., Franc, A., Commère, P.H., Schermann, N., Bastien, J.C., 1997. Height growth, wood density and dry fibre weight of four 33 year-old Douglas-fir provenances. In: Proceedings of CTIA/IUFRO International Wood Quality Workshop. Timber Management Toward Wood Quality and End-Product Value, Vancouver, Canada, 18-22 August, 83-90. Rozenberg, P., Franc, A., Bastien, C., 2001. Improving models of wood density by including genetic effects: A case study in Douglas-fir. Ann. For.Sci. 58, 385-394.

Rozenberg, P., Van Loo, J., Hannrup, B., Grabner, M. 2002. Clonal variation fo wood density record of cambium reaction to water deficit in Picea abies (L.) Karst. Ann. For.Sci. 59, 533540.

Rozenberg, P., Pâques, L., 2004. Evidence of the effect of the climate of year 2003 on Douglas-fir and larch wood formation in France. In: Abstract proceedings of conference Impacts of the Drought and Heat in 2003 on Forests. Freiburg, Germany, 17-19 November, 38. 
Rozenberg, P., Schüte, G., Ivkovich, M., Bastien, C., Bastien, J.C., 2004. Clonal variation of indirect cambium reaction to within-growing season temperature changes in Douglas-fir. Forestry 77, 257-268.

Salinger, S., 2005. Increasing climate variability and change: reducing the vulnerability. Climatic Change, 70, 1-3.

Sanchez-Vargas, N., Sanchez, L., Rozenberg, P., 2007. Plastic and adaptive response to weather events: a pilot study in a maritime pine tree ring, Can. J. For. Res. 37, 2090-2095. Saxe, H., Cannel, M.G.R., Johnsen, Ø., Ryan, M.G., Vourlitis, G., 2001. Tree and forest functioning in response to global warming. New Phytol. 149, 369-400.

Schär, C., Vidale, P.L., Lüthi, D., Frei, C., Häberli, C., Mark, A., Liniger, M.A., Appenzeller, C., 2004. The role of increasing temperature variability in European summer heatwaves. Nature 427, 332-336.

Scheider, S.M., Lyman, R.F., 1989. The genetics of phenotypic plasticity. I Heritability. J. Evol. Biol. 2, 95-107.

Schiller, G., Cohen, Y., 1995. Water regime of a pine forest under a Mediterranean climate. Agr. For. Meteorol. 74,181-193.

Sperry J.S., Hacke U.G., Pittermann J., 2006. Size and function in conifer tracheids and angiosperms vessels. Am. J. Bot. 93, 1490-1500.

St. Clair, J.B., 1994. Genetic variation in tree structure and its relation to size in Douglas-fir. I. Biomass partitioning, foliage efficiency, stem form and wood density. Can. J. For. Res. 24, 1226-1235.

St. Clair, J.B., Howe G., 2007. Genetic maladaptation of coastal Douglas-fir seedlings to future climates. Global Change Biol. 13, 1441-1454.

Stratton, L., Goldstein, G., Meinzer, F., 2000. Stem water storage capacity and efficiency of water transport: their functional significance in a Hawaiian dry forest. Plant Cell Environ. 23, 99-106.

Taiz, L., Zeiger, E., 2006. Plant physiology. Sinauer Associates, Inc.

Thivolle-Cazat, A. 2004. Le Douglas en France : une ressource résineuse en pleine expansion. Available in: http://www.afocel.fr/Foret/Ressources/Douglas/4\%20pagesF.Douglas.pdf Tyree, M., Sperry, J., 1989. Characterization and propagation of acoustic-emission signal in woody-plants-towards an improved acoustic-emission counter. Plant Cell Environ. 12, 371382.

Tyree, M.T., Zimmerman, M.H., 2002. Xylem structure and the ascent of sap, Second edition. Springer-Verlag Berlin and Heidelberg GmbH \& Co. K, Second edition.

Vargas-Hernandez, J., Adams, W.T., Krahmer, R.L., 1994. Family variation in age trends of wood density traits in young coastal Douglas-fir. Wood Fiber Sci. 26, 229-236.

Waring, R., Running, S., 1978. Sapwood water storage: its contribution to transpiration and effect upon water conductance through the stems of old-growth Douglas-fir. Plant Cell Environ. 1, 131-140.

Zahner, R., 1968. Water deficits and growth of trees. In: Water deficits and plant growth (eds Kozlowski TT). Academic Press, New York, pp 191-254.

Zamudio, F., Rozenberg, P., Baettig, R., Vergara, A., Yañez, M., Gantz, C., 2005. Genetic variation of wood density components in a radiata pine progeny test located in the south of Chile. Ann. For.Sci. 62, 105-114.

Zobel, B.J., Jett, J.B., 1995. Genetics of wood production. Springer-Verlag. Zobel, B., van Buijtenen, J., 1989. Wood variation its causes and control. Springer-Verlag. 


\section{FIGURE LEGENDS}

Fig. 1 Microdensity profiles of two trees: one tree that survived 2003 but perished in the following year and a surviving tree, from our sample in Orléans Douglas-fir forest.

Fig. 2 Tree distribution in provenance trial and pairs of sampled trees (dead and associated living trees).

Fig. 3 Differences between living and dead trees for variable i and year $\mathrm{j}\left(\mathrm{D} 1_{\mathrm{ij}}\right.$ ) for ring width (a), minimum ring density (b) and earlywood density (c) in solid line. The solid grey bars show the $\log 10$ of the probability associated to $\mathrm{D} 1_{\mathrm{ij}}$ in the Monte-Carlo randomization process. The horizontal line represents the $5 \%$ significance level.

Fig. 4 Differences between living and dead trees in variable i in year j (D1 $\left.1_{i j}\right)$ for mean ring density (a), maximum ring density (b), latewood density (c) and latewood proportion (d). The solid grey bars show the $\log 10$ of the probability associated to $\mathrm{D} 1_{\mathrm{ij}}$ in the Monte-Carlo randomization process. The horizontal line represents the $5 \%$ significance level.

Fig. 5 Illustration of the mean latewood density and mean latewood proportion in living (dark grey circles) and dead (light grey diamonds) trees, for the outermost year-rings (from 1999 to 2002). Full big circle and diamond and their solid lines represent the mean value and standard deviation of each group of trees (living and dead trees respectively). 
TABLES

Table 1 Average, D1 differences and standard deviation and p-value for mean stem wood density and diameter growth in surviving and dead Douglas-fir trees.

\begin{tabular}{lcc}
\hline & $\begin{array}{c}\text { Mean Stem Density } \\
\left(\mathrm{g} / \mathrm{cm}^{3}\right)\end{array}$ & $\begin{array}{c}\text { Diameter Growth } \\
(\mathrm{mm})\end{array}$ \\
\hline Average surviving trees & $468.41 \pm 37.33$ & $229.29 \pm 40.42$ \\
Average dead trees & $457.28 \pm 30.67$ & $226.47 \pm 39.94$ \\
D1 differences & $11.13 \pm 47.74$ & $2.82 \pm 51.77$ \\
Significance & 0.031 & 0.364 \\
\hline
\end{tabular}

